\title{
A construção da condição fronteiriça do oeste amapaense (1947-2014)
}

Jadson Luis Rebelo Porto

Programa de Pós-Graduação em Desenvolvimento Regional da Universidade Federal do Amapá (Unifap)

Recebido: 21/04/2014 Versão revisada (entregue): 16/05/2014 Aprovado: 23/05/2014

\begin{abstract}
Resumo
Estudos sobre o tema "fronteira" são bastante diversificados, variados e multidisciplinares na literatura. Neste artigo debruçou-se sobre os usos da fronteira, em especial, a fronteira oeste amapaense como integrante da Faixa de Fronteira brasileira. Para a presente reflexão adota-se como marco temporal de análise o período pós-década de 1940, quando foi criado o Território Federal do Amapá. Dos 16 municípios amapaenses, oito se encontram inseridos na faixa de fronteira brasileira. Desses, selecionaram-se os municípios de Serra do Navio e Pedra Branca do Amapari. A sua escolha é decorrente da construção da condição fronteiriça do oeste amapaense, distinta dos demais espaços deste ente federativo, onde predomina uma condição estratégicoperiférica institucionalizada. Com este artigo visa-se refletir sobre a construção do uso da fronteira ocidental amapaense, a partir da configuração territorial conjunta dos municípios de Serra do Navio e Pedra Branca do Amapari, como fronteira acionada, precariamente articulada, porém, desconectada de sua linde internacional, inserida em uma regionalização nacional fronteiriça, e detentora de uma condição fronteiriça estratégico-periférica. Três aspectos são, especialmente, considerados: a condição fronteiriça amapaense, o oeste amapaense como uma fronteira desconectada com a linde, mas inteirada com o mundo, e a condição estratégicoperiférica da linde ocidental amapaense.
\end{abstract}

Palavras-chave | Amapá; condição fronteiriça; uso da fronteira.

Código JEL | F13; O19; R11.

\section{THE CONSTRUCTION OF THE BORDER CONDITION OF WESTERN AMAPÁ} (1947-2014)

\begin{abstract}
Studies on the topic of "borders" are quite diverse, varied and multidisciplinary in literature. This article focused on the uses of the border, in particular the Amapá western border as part of the Brazilian Border Strip. For the present discussion it is adopted the timeframe analysis of the post-decade period from 1940, when the Federal Territory of Amapá was created. Eight of the 16 municipalities in Amapá are inserted in the Brazilian border strip. Here we selected the municipalities of Serra do Navio and Pedra Branca do Amapari. This choice is due to the construction of the border condition of western Amapá, distinguished from other areas of this federal entity, dominated by an institutionalized strategic-peripheral condition. This article aims
\end{abstract}


to reflect on the construction of the use of the western Amapá border, from the perspective of the territorial conjunction of the municipalities of Serra do Navio and Pedra Branca do Amapari. It constitutes a driven, poorly articulated border, however disconnected from its international abut, inserted into a national border regionalization, and holding a strategicperipheral border condition. Three aspects are especially considered: the borderline condition of Amapá, the western Amapá disconnected border from the abut, but connected to the world, and the strategic-peripheral condition of the western Amapá abut.

Keywords | Amapá; borderline condition; use of the border.

JEL-Code | F13; O19; R11.

\section{LA CONSTRUCCIÓN DE LA CONDICIÓN FRONTERIZA EN EL OESTE DE AMAPÁ (1947-2014)}

\section{Resumen}

Estudios sobre el tema "frontera" son bastante diversificados, variados e multidisciplinarios en la literatura. En este artículo nos hemos dedicado a los usos de la frontera, en especial a la frontera oeste del Estado de Amapá como integrante de la Franja de Frontera brasileña. Para esta reflexión se adopta como marco temporal de análisis el período pos década de 1940, cuando fue creado el Territorio Federal de Amapá. De los 16 municipios amapaenses, 8 se encuentran inseridos en la franja de frontera brasileña. Entre ellos fueron seleccionados los municipios de Sierra del Navío y Piedra Blanca de Amapari. Esta elección resulta de la construcción de la condición fronteriza del oeste amapaense, diferente de los demás espacios de este ente federativo, en el cual predomina una condición estratégico-periférica institucionalizada. Con este artículo lo que se busca es reflexionar sobre la construcción del uso de la frontera occidental amapaense a partir de la configuración territorial conjunta de los municipios de Sierra del Navío y Piedra Blanca Amapari como frontera precariamente articulada y, sin embargo, desconectada de su límite internacional, inserida en una regionalización nacional fronteriza, detentora de una condición fronteriza estratégico-periférica. Tres aspectos son especialmente considerados: la condición fronteriza amapaense, el oeste amapaense como una frontera desconectada con el límite, pero integrada con el mundo y la condición estratégico-periférica del límite occidental amapaense.

Palabras-clave | Amapá; condición fronteriza; uso de la frontera.

Código JEL | F13; O19; R11.

\section{Introdução}

Estudos sobre o tema fronteira são bastante diversificados, variados e multidisciplinares na literatura acadêmica mundial. Para a elaboração deste artigo, debateu-se sobre os usos da fronteira, em especial a fronteira oeste amapaense como 
integrante da Faixa de Fronteira brasileira ${ }^{1}$. Segundo Silva (2008, p. 48), nesta faixa "o programa das ações conjuntas se define, geralmente, para ser aplicado às jurisdições politicas internas de cada pais. São, também, denominadas de regiões de programação que abarcam, em algumas oportunidades, superfícies consideráveis em cada território nacional".

Para as reflexões aqui tecidas sobre a fronteira amapaense, adota-se como marco temporal de análise o período pós década de 1940, quando foi criado o Território Federal do Amapá (como elemento reconstrutor de políticas públicas na fronteira, ao receber elevados investimentos infraestruturais e permitir a lenta e gradual construção de efeito-cooperação com o Platô das Guianas); quando ocorreram intensas transformações espaciais decorrente da exploração mineral inicialmente pelo manganês, ouro e ferro, ampliando sua inserção no cenário global articulada em rede; e pela mudança de uso do território de espaço de expansão para espaço de restrição.

Destaque-se, também, que até 1986 todo o estado do Amapá estava inserido dentro da faixa de fronteira brasileira, quando possuía somente cinco municípios (Oiapoque, Calçoene, Amapá, Macapá e Mazagão). A partir de 1987, novos municípios foram criados, sendo que alguns deles saíram da faixa (Macapá e Mazagão), e outros foram criados fora da faixa (Santana, Ferreira Gomes e Tartarugalzinho) e um novo município dentro da faixa (Laranjal do Jari); na década de 1990 foram criados quatro municípios fora desta faixa (Cutias, Porto Grande, Itaubal e Vitória do Jari) e também novos foram inseridos na faixa (Serra do Navio, Pedra Branca do Amapari, Pracuúba).

Localizado na Fronteira da Amazônia Setentrional, o Amapá limita-se internacionalmente com a Unidade Ultramarina francesa (Guiana) e Suriname; os municípios de Serra do Navio e Pedra Branca do Amapari ambos localizados no

\footnotetext{
${ }^{1}$ Segundo o Grupo Retis, a primeira vez em que a faixa de fronteira foi definida no Brasil como área geográfica com regime jurídico particular foi no final do século XIX, pela Lei nº. 601, de 18 de setembro de 1890, que reservou uma faixa de 10 léguas $(66 \mathrm{~km})$, ao longo do limite do Território Nacional, cujas terras devolutas poderiam ser concedidas pela União. $\mathrm{Na}$ década de 1930, a faixa de fronteira foi sendo sucessivamente ampliada de $66 \mathrm{~km}$ para $100 \mathrm{~km}$, e depois para $150 \mathrm{~km}$ (Constituições de 1934 e 1937, respectivamente). Em 1955, a Lei No 2.597 define as zonas indispensáveis à defesa nacional, mantendo entre elas a faixa de fronteira de $150 \mathrm{~km}$ como zona de segurança e estabelece que a União aplique anualmente $60 \%$ de sua arrecadação na faixa, especificamente em viação e obras públicas, ensino, educação e saúde e desenvolvimento da lavoura e da pecuária; é regulada pela Lei $\mathrm{n}^{\circ}$. 6.634/1979, que identifica a faixa de fronteira brasileira como uma região estratégica ao Estado Nacional. Esta faixa é uma região de programação com $150 \mathrm{~km}$ de largura a partir do limite internacional continental, ao longo de $15.719 \mathrm{~km}$ da fronteira terrestre brasileira desde a foz do rio Oiapoque (AP) à foz do arroio Chuí (RS); abrange 11 unidades da Federação e 588 municípios e reúne aproximadamente 10 milhões de habitantes (http://igeo-server.igeo.ufrj.br/fronteiras/programafronteira/tikiindex.php?page=Legislação+Vigente\&structure =Legislação\&page_ref_id=175).
} 
centro-oeste amapaense e criados na década de 1990, embora suas atividades remetam à exploração manganesífera iniciada na década de 1950.

Dos 16 municípios amapaenses, oito se encontram inseridos na faixa de fronteira brasileira: Oiapoque, Laranjal do Jari, Amapá, Serra do Navio, Pedra Branca do Amapari, Calçoene, Pracuúba e Ferreira Gomes (Figura 1). Desses, somente o primeiro possui sede localizada no limite internacional; o segundo possui o seu território na divisa com o pais vizinho, porém sua sede não se situa no limite internacional; os demais são municípios não-lindeiros com sede na Faixa de Fronteira. Desses, selecionou-se os municípios de Serra do Navio e de Pedra Branca do Amapari para colaborar no debate sobre a condição fronteiriça amapaense a partir das reflexões trabalhadas por Porto (2010a; 2010b; 2014).

A escolha desses dois municípios é decorrente da construção da condição fronteiriça do oeste amapaense, que é distinta dos demais espaços deste ente federativo, onde predomina uma condição estratégico-periférica institucionalizada, devido aos seguintes fatores: sua construção histórica está assentada na exploração mineral desde a década de 1950, com forte participação do capital internacional na organização de seus espaços; possuem grande participação na balança comercial amapaense; mais de $70 \%$ de seus territórios são compostos por espaços de restrição (unidades de conservação e terra indígena), além do que a área de seus municípios é desconectada da relação com fronteira (embora ambos se localizem na faixa de fronteira brasileira), mas se articula com a economia-mundo pelo Porto de Santana, no Amapá, fora da faixa de fronteira.

\section{Figura 1 - Municípios amapaenses na Faixa de Fronteira}

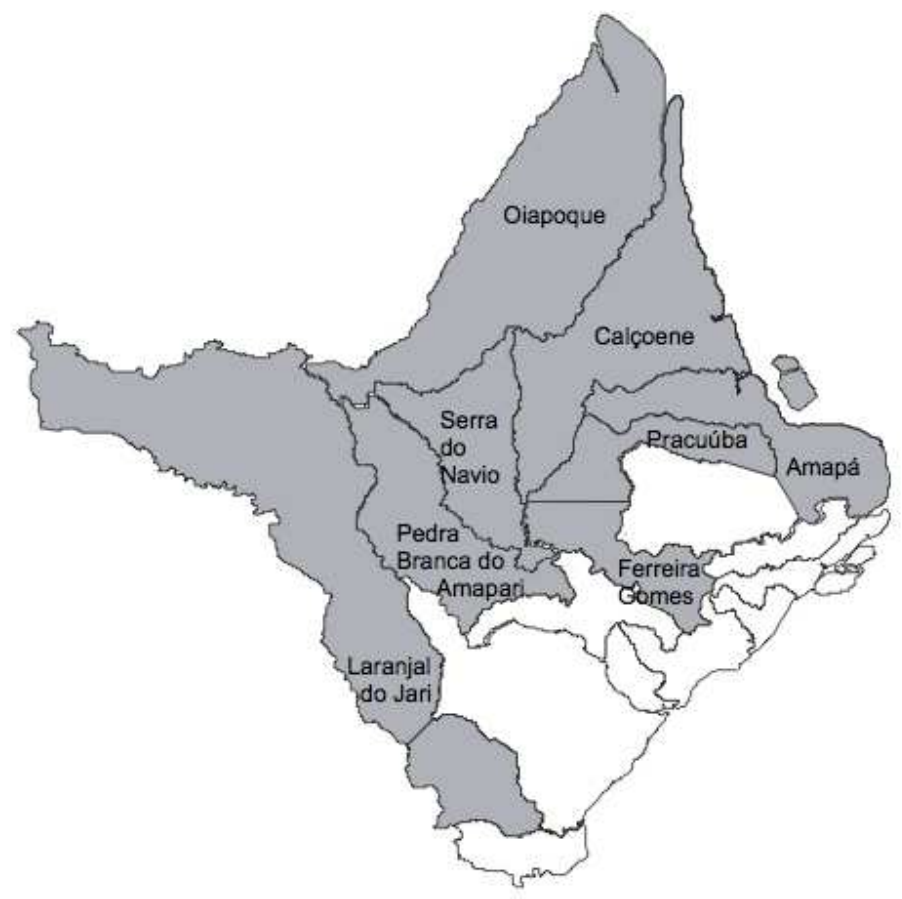


Este artigo visa refletir sobre a construção do uso da fronteira ocidental amapaense, a partir da configuração territorial conjunta dos municípios de Serra do Navio e Pedra Branca do Amapari, como uma fronteira acionada, precariamente articulada, porém não conectada com a sua linde internacional; inserida em uma regionalização nacional fronteiriça e detentora de uma condição fronteiriça estratégico/periférica.

Para a construção deste debate, três tópicos são expostos: o primeiro aborda uma reflexão sobre a condição fronteiriça amapaense; o segundo analisa o oeste amapaense como uma fronteira desconectada com a linde, mas interada com o mundo; por último, explicita a condição estratégico/periférica da linde ocidental amapaense.

\section{A condição fronteiriça amapaense}

Para a construção da condição fronteiriça amapaense, adota-se o pensamento miltoniano (SANTOS, 1996) no que diz respeito ao uso da fronteira como sistemas de objetos, que condicionam a forma como se dão as ações; e no que diz respeito à condição fronteiriça como sistema de ações, que leva à criação de objetos novos ou se realiza sobre objetos preexistentes. Também há uma idade do lugar como materialidade artificial, que indica a linde amapaense como uma fronteira tardia. Entende-se que esta fronteira tardia é decorrente de uma construção externa, em que as ações estimulam os objetos técnicos, formando e transformando os "espaços derivados" miltonianos ${ }^{2}$ da materialidade artificial. E também se entende que os sistemas de objetos e de normas existentes não são suficientes para atender às novas dinâmicas territoriais, exigindo a criação de novas normas e estruturas físicas que visam estabelecer critérios para o (des)(re)uso ou o não uso do território. Aqui se apresenta um sistema híbrido dos circuitos superior e inferior da economia.

Mello (1998) afirma que o Brasil possui um capitalismo tardio, enquanto Carvalho (1999) insere a Amazônia nesta discussão e indica-a como sendo capitalismo tardio periférico. No caso específico amapaense, Porto tem trabalhado em várias ocasiões como um capitalismo tardio periférico da periferia, ao analisar a construção de suas relações econômicas após a década de 1940, sendo que a fronteira setentrional amapaense, a partir de Macapá, foi conectada pela via rodoviária somente após a década de 1980, mas com Caiena, em 2004. Quanto à fronteira ocidental

\footnotetext{
${ }^{2}$ Segundo Pereira (2010), os espaços derivados são "aqueles onde os processos de modernização e transformação regionais estão diretamente relacionados a anseios externos, às demandas longínquas".
} 
amapaense, esta não é conectada integralmente, pois inexistem vias de fluidez à linha de fronteira semelhantes à anterior.

Grimson (2003, p. 17) analisa as fronteiras como "os regimes de movimentos materiais e simbólicos que através delas incluem uma serie de relações econômicas, políticas, sociais e culturais". Porém, seus sentidos são decorrentes da conjunção dos seguintes elementos formadores: território, população, regimes de fluxos e de outras relações sócio-históricas. Neste sentido, "a fronteira nunca é um dado fixo, mas um objeto inacabado e instável. Um objeto disputado de diversas formas. Um objeto que como produto histórico de ação humana pode ser e é reestruturado e resignificado." (GRIMSON, 2009, p. 17).

A partir deste foco, adota-se, aqui, o pensamento de Grimson (2003) e o de Foucher (2009) e insere-se no debate o que Adriana Dorfman chamou de "condição fronteiriça"3. Dorfman (2013) apresenta a condição fronteiriça como

um savoir passer [saber passar] adquirido pelos habitantes da fronteira, acostumados a acionar diferenças e semelhanças nacionais, linguísticas, jurídicas, étnicas, econômicas, religiosas que ora representam vantagens, ora o cerceamento de transito ou direitos. (...) Evidentemente, deve-se duvidar de uma condição fronteiriça universal, haja vista a variedade de relações que podem existir entre os fronteiriços e o território estatal a sua frente e as suas costas: o que temos idealizado aqui diz respeito à fronteira viva e vivida.

A construção histórica, social, econômica e politicamente estabelecida pelas suas relações locais (como espaço vivo e vivido) e externas (como espaço relacional) para a construção desta condição, corrobora a tese de fronteira como um produto historicamente construído, reestruturado e resignificado. Com isso, a condição fronteiriça é constantemente (re)inventada. Ou seja, a cada momento histórico ela é refeita, é recomposta, por ser social e politicamente estabelecida, como um espaço de dialogo e/ou de conflitos.

Quais seriam as características da condição fronteiriça? A partir das obras de Porto (2010a; 2010b; 2010c; e 2013) identificam-se contextos territoriais que permitem a construção de um perfil de comportamentos sociais, culturais, econômicos e políticos capazes de (des)(re)construir os usos do território fronteiriço, tais como: possibilitar conflitos entre o tradicional e o moderno; garantir ações para a (des)(re)organização espacial e não estipula atos para a sua execução; apresenta-se como um lócus de oportunidades, tolerâncias e flexibilidades de uso do território;

\footnotetext{
${ }^{3}$ Esta categoria foi apresentada em uma mesa redonda do XII Encuentro de Geógrafos da América Latina, em Montevidéu (2009), por Adriana Dorfman. Em 2013, a autora resgata a categoria e compara os casos riograndense e amapaense.
} 
e as novas modalidades deste uso, que dinamizam suas articulações nas diversas escalas espaciais.

Com essas características, percebe-se que o contato existente na fronteira entre o local e o internacional impõe um dinamismo próprio a este espaço; exigindo dos seus atores posturas que, em diversos momentos, são conflitantes às determinações legais, mas que são executadas devido a diversos interesses que esses atores se disponibilizam a executar ou conquistar. Os conflitos legais necessariamente indicam a ilegalidade de ações, mas, em muitos casos, originam-se na inexistência de um arcabouço de normas direcionadas, seja às especificidades locais que a fronteira possui, seja às relações diplomáticas de um espaço ainda com manifestações de efeito-barreira.

Neste rumo, a condição fronteiriça amapaense está diretamente ligada aos movimentos de (des)(re)construção e (des)(re)territorialização; à grande atuação do Estado, porém com fraca fiscalização; à criação/construção de próteses dos mais variados modelos; à existência, configuração e intensidade de articulação das redes existentes, as quais expressam reflexos de cenários internacionais; às expectativas de integração com a Guiana Francesa; às suas restrições espaciais; e sua posição na economia-mundo como fornecedora de commodities e consumidora de produtos industrializados.

Quanto à construção da condição fronteiriça amapaense, observa-se que está embasada em três fatores: enquanto resultado de efeito-barreira; enquanto construção de efeito-cooperação; e enquanto integração na economia-mundo.

O primeiro fator expõe a construção histórica e geopolítica expansionista do período colonial e dos reflexos de tratados na Europa que afetassem as fronteiras francesas trabalhadas no capítulo 3. Contudo, embora as barreiras diplomáticas ocorressem, relações econômicas e sociais locais no Platô das Guianas eram exercidas. Romani (2003) e Reis (1993) relatam as interações sociais e econômicas entre o norte amapaense e a Guiana Francesa no século XIX.

O segundo retrata os ensaios recentes de cooperação entre o Amapá e a Guiana Francesa. A construção desta cooperação, por enquanto é estimulada pela integração física entre esses espaços mediante a construção e pavimentação rodoviária Macapá/Caiena; a construção da ponte binacional no rio Oiapoque; a ampliação do sistema portuário de Santana (Amapá/Brasil); e a construção institucional de relações de cooperação entre Amapá e Guiana Francesa.

O terceiro diz respeito às funções do Amapá e da Guiana Francesa na economiamundo. Como esses territórios são envolvidos nas relações econômicas mundiais? As orientações para a formação e formatação desses territórios têm origem externa, a exemplo das ações de empresas internacionais que exploram seus recursos naturais ali onde estão instaladas (CHELALA, 2008). Elas remetem à inserção da Guiana Francesa nas políticas da França e União Europeia, como Departamento Ultramarino e Ultraperiférico, respectivamente. Elas incluem a 
inserção da Estação Espacial de Kouru, como um centro de altíssima tecnologia da União Europeia. Elas, finalmente, apontam para o posicionamento geográfico na foz do rio Amazonas e no ambiente amazônico, cujo potencial de biodiversidade é elevado a enésima potência quando se inserem técnica e tecnologia ao seu uso e exploração.

Com esses fatores, Porto (2014) indica que a condição fronteiriça amapaense tem se apresentado como resultado: de orientações externas e transoceânicas; das tensões e contradições multiescalares; do exercício da soberania dos Estados nacionais; de acordos formais dos territórios estatais próximos fisicamente e informais pela população instalada e interagida; de uma fronteira porosa; de acordos formais internacionais; da recente necessidade de se construir políticas territoriais conjuntas e solidárias entre Amapá e Guiana Francesa; e de constantes ajustes espaciais ${ }^{4}$ para construções de interações, articulações e usos do território tardios.

Neste sentido, a fronteira amapaense por um lado é considerada na escala nacional como periférica, mas, por outro, é extremamente estratégica na internacional, pois, sobre esta última condição, se articula com um membro integrante da União Europeia (Guiana Francesa) e possui matérias-primas de elevado interesse mundial: minérios, alimentos, biodiversidade, água potável, e, mais recentemente, oferta de serviços ambientais (2008), com o lançamento de edital de exploração madeireira na Floresta Estadual de Produção - Flota (2014); a descoberta e intenção de exploração de petróleo na plataforma continental em frente à costa amapaense, em 2013.

Outro aspecto identificado na condição fronteiriça amapaense diz respeito à revisão das posturas geopolíticas da fronteira em momentos históricos distintos (seja com a evidência de efeitos-barreira, seja na construção de efeitos-cooperação) e das

\footnotetext{
${ }^{4}$ Segundo Harvey, (2005, p. 9), “a tese do ajuste espacial somente tem sentido se relacionada com a tendência expansiva do capitalismo, entendida teoricamente mediante a teoria marxista da queda da taxa de lucros que produz crises de super-acumulação". Na versão brasileira dos "Limites do capital" (2013), na introdução à edição inglesa de 2006, Harvey indica que "ajustes espaciais" são expansões/reestruturações geográficas (p. 22). Porto et al. (2007), por sua vez, interpretaram que "ajustes espaciais" são as adaptações que são efetivadas no espaço, visando a garantia da instalação, existência, fluidez, manifestação e reprodução do capital. Os ajustes espaciais também permitiram que o Amapá fosse (re)acionado pelo capital interessado pelas suas potencialidades naturais, inicialmente mineral (manganês, ferro, ouro, caulim, tantalita, cromita); posteriormente por terras para silvicultura, alimentos (pesca, açaî) e cosméticos (óleo da castanha); pelas relações comerciais internacionais via exportação de commodities e importação pela ALCMS; e, mais recentemente, pela inserção do Amapá na oferta de serviços ambientais, pelo crédito de carbono (2010); pela inserção de banda larga, vinda pela Guiana Francesa, via rede mundial da internet (2013); e pela oferta de exportação energética (previsto para 2014). A fronteira amapaense se torna mais articulada e mais dinâmica, mais global (PORTO; SUPERTI; SILVA, 2013), embora seja tardia (PORTO, 2014).
} 
ações do Estado na (des)construção territorial de espaços fronteiriços como ator determinante para promoção de processos de ordenamento territorial, reestruturação produtiva, espacial, exploração de novos mercados, e integração nacional e internacional (Eliane Superti, em entrevista, 2013). Com isso, há recomposições de uso do território com ajustes espaciais e redesenhos de sua configuração territorial.

Outro aspecto da fronteira tardia amapaense é a nova articulação internacional em construção, em que a interação espacial do espaço amapaense extrapola o circuito flúvio-marítimo (PORTO; SUPERTI; SILVA, 2013), para se inserir novos eixos de circulação no espaço amapaense: o rodoviário com articulações transfronteiriças (Figura 2).

A partir da década de 1950, o eixo rodoviário/ferroviário articula o oeste amapaense com o litoral, ligando Serra do Navio ao Porto de Santana, na exportação de minérios. Na década de 1980, inserem-se dois eixos de articulação. $\mathrm{O}$ primeiro foi a instalação do $\mathrm{CIJ}$ no município de Almerim (PA), às margens do rio Jari (rio que separa o estado do Pará do Amapá), exportando celulose, caulim, e chegando a exportar bauxita refratária na década de 1990. O segundo foi a conexão via rodoviária Oiapoque-Macapá, pela BR-156, acessando a fronteira Amapá-Guiana. Com isso, a fronteirização se tornou mais dinâmica, embora ainda permanecesse o tempo-lento miltoniano decorrente da não pavimentação completa dessa rodovia até 2013. 
Figura 2 - Sistema rodoviário transfronteiriço franco-brasileiro

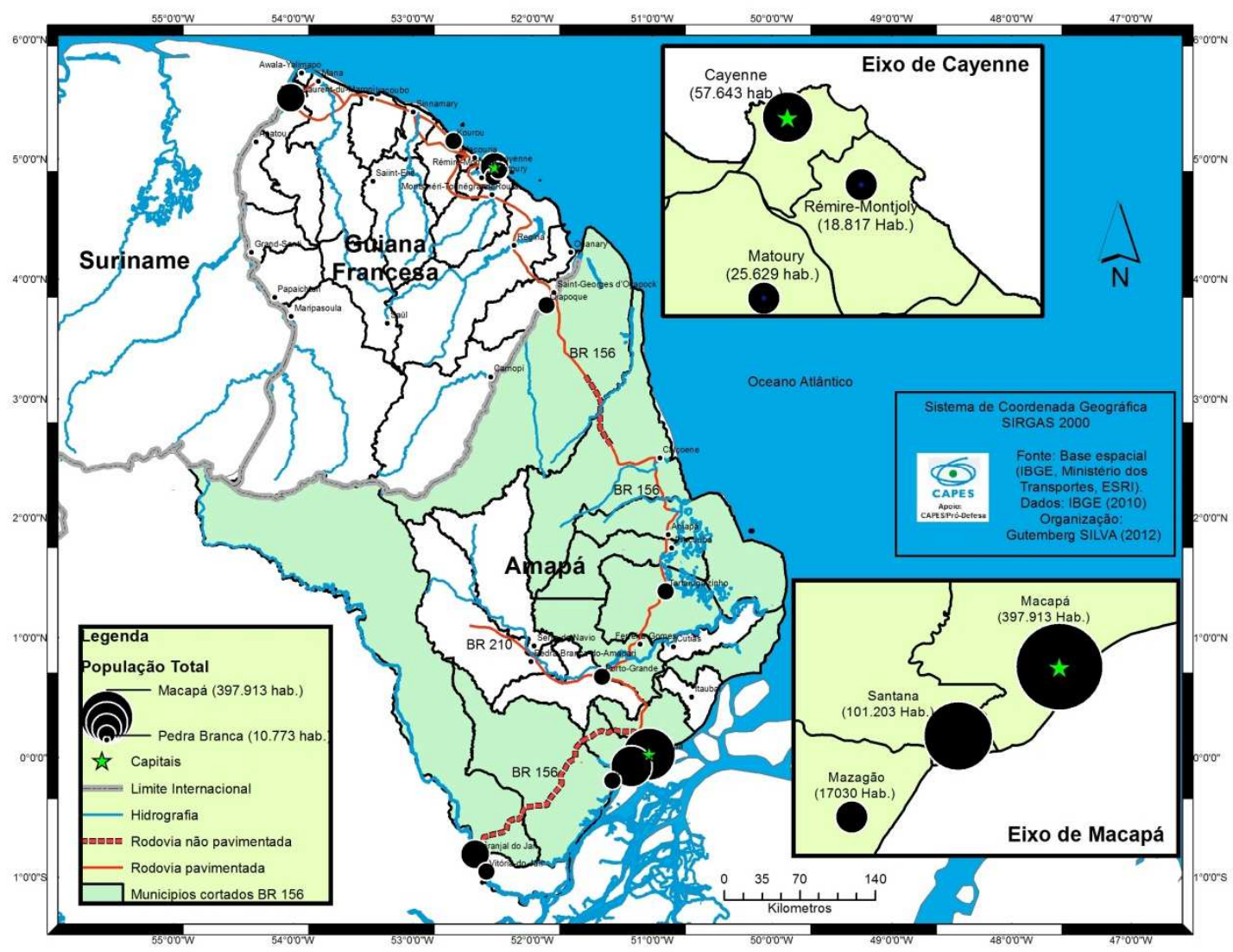

No início da década de 1990, a BR-156 chegou ao sul do estado do Amapá, no município de Laranjal do Jari. Assim, a coluna vertebral rodoviária ficou completa no sentido Norte-Sul. Agora a possibilidade circulação via rodoviária articula o limite com o Pará, onde se encontra o grande capital do CIJ; o Oeste amapaense, onde se encontra o grande capital mineral; o Norte, onde se conecta e interage com a fronteira francesa, um representante de União Europeia; o Centro, onde se localizam as UHE de Coaracy Nunes, Caldeirão, Ferreira Gomes (que exportarão energia para o sul do país pela integração ao sistema elétrico nacional) e a produção de silvicultura para a produção de celulose; e o Leste, onde se encontram as cidades mais populosas e dinâmicas economicamente (Macapá e Santana), o sistema portuário de Santana, sendo este atuante na exportação de minérios e cavacos para celulose, importação de bens manufaturados para a ALCMS e a movimentação de passageiros (seja para turismo internacional via transatlânticos, seja para recepção de migrantes oriundos da região ou de outros estados brasileiros).

No que se refere a rodovia da BR-156, esta é a única rodovia federal que inicia e termina em uma única unidade da federação. Com cerca de $900 \mathrm{~km}$, foi construída a partir da década de 1940, para interligar a cidade de Macapá e Clevelândia do Norte, fronteira com a Guiana Francesa. Este trecho foi concluído na década de 
1980. O trecho sul, conectando Macapá-Laranjal do Jari, limite com o estado do Pará, foi concluído em 1991 (Figura 2).

Neste sentido, a configuração territorial rodoviária possui construções espaciais e demográficas distintas (Gráfico 1) ${ }^{5}$. No período 1950-2010, há dois momentos de intercessão no comportamento demográfico que precisam ser explicados. O primeiro cruzamento (década de 1970), indicando o eixo sul sendo superior ao eixo norte, decorre da instalação do CIJ, às margens do rio Jari, no município de Almerim (PA). Vale ressaltar que até a segunda metade da década de 1980, o eixo sul desta rodovia não estava pronto. O acesso dava-se via hidroviária, pelos rios Amazonas e Jari.

\section{Gráfico 1 - População amapaense ao Norte, ao Sul e a Oeste do eixo Macapá-Santana}

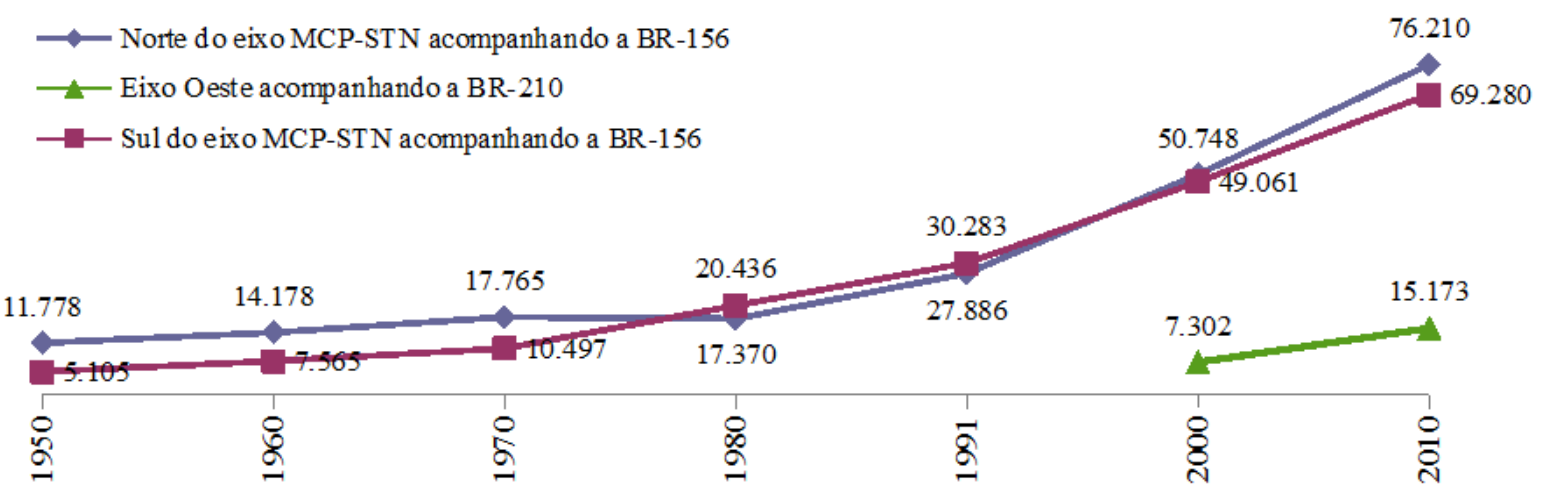

Fonte: IBGE.

O segundo cruzamento, na década de 1990, é explicado pela movimentação de brasileiros em busca de ouro na região da fronteira, tanto do lado brasileiro, quanto francês. Observe-se também a contemporaneidade do movimento pela criação do bloco da União Europeia (1992), sendo a Guiana Francesa inserida nesta dinâmica, atraindo brasileiros em busca de melhores condições econômicas. Esses cruzamentos podem ser observados quando esses índices são sobrepostos aos índices de desmatamento, e se espacializa na cartografia amapaense. (Figura 3).

\footnotetext{
${ }^{5}$ Para a elaboração do Gráfico 1, calculou-se o total da população por município por onde as rodovias BR-156 e BR-210 passam, exceto as populações de Macapá e Santana. No trecho norte, a rodovia passa pelos municípios amapaenses de: Ferreira Gomes, Porto Grande, Pracuúba, Tartarugalzinho, Amapá, Calçoene e Oiapoque. No trecho sul, Mazagão, Laranjal do Jari e Vitória do Jari. O ramo oeste é percorrido pela BR-210 e passa por Serra do Navio e Pedra Branca do Amapari. Embora essa última rodovia inicie em Macapá e também percorra os municípios de Ferreira Gomes e Porto Grande, optou-se por calcular somente Serra do Navio e Pedra Branca do Amapari e considerar os demais municípios como inseridos no eixo da BR156.
} 
Figura 3 - Frente de desmatamento no Estado do Amapá (2009)

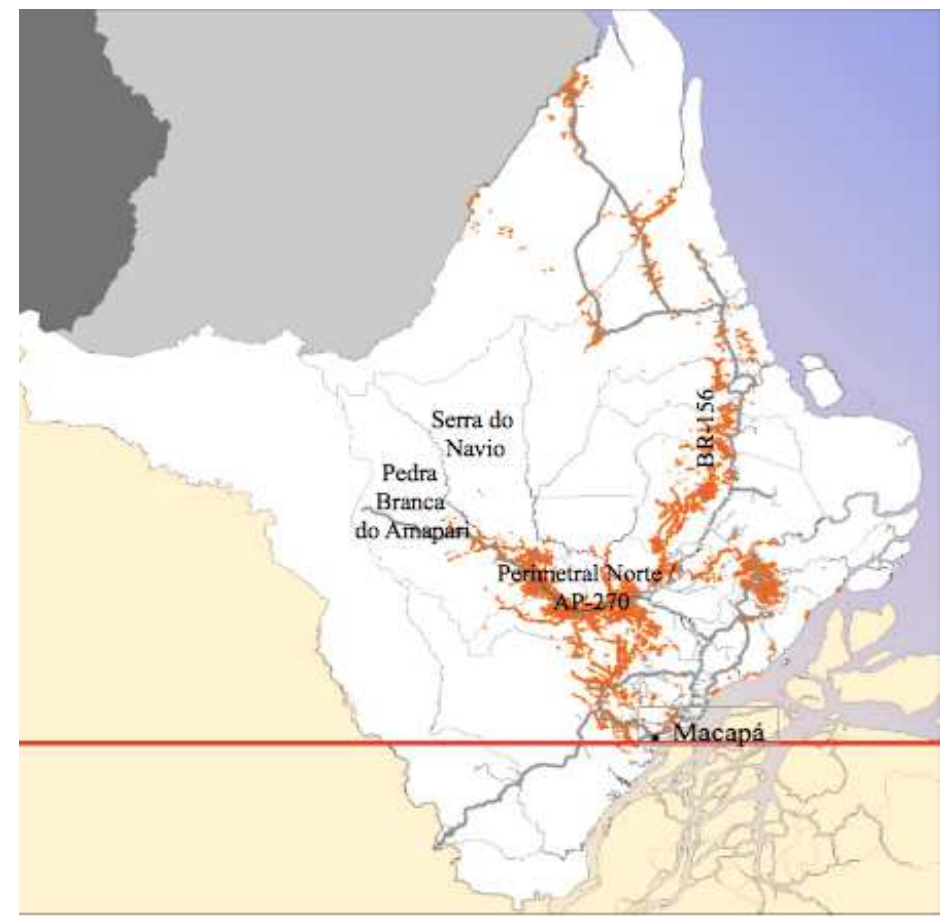

Fonte: IEPA.

Quanto ao eixo oeste, o comportamento de crescimento se explica por dois fatores: o primeiro diz respeito à criação dos municípios de Serra do Navio e Pedra Branca do Amapari, ambos em 1992. Contudo, embora a ocupação desses municípios possua informações desde a década de 1950, com a atuação da exploração do manganês, seus registros demográficos estavam vinculados ao município de Macapá. O segundo fator é decorrente da recuperação da economia mineira em Pedra Branca do Amapari (2004), atraindo novos trabalhadores para a região.

A partir do entendimento de Porto, Superti e Silva (2013), conclui-se que, no caso amapaense, a fronteira setentrional não se refere somente à fronteira continental. Defende-se aqui que outros fenômenos geográficos devem ser inseridos nas discussões sobre essa linde, os quais perpassam pela construção do espaço amapaense em momentos distintos de sua história, da geopolítica, da economia e suas interações espaciais em rede, cuja manifestação no seu território é uma construção desigual, contraditória e solidária; e de espaços de atuação do grande capital internacional.

Quando se insere nesta discussão o oeste amapaense, cinco discussões são identificadas e que carecem de análises aprofundadas sobre o seu uso territorial e a ocorrência de espaços de restrição:

i) a ocorrência de áreas institucionais de unidades de conservação em níveis federal, estadual e municipal (Parque Nacional Montanhas do Tumucumaque, 
Reserva de Desenvolvimento Sustentável do Rio Iratapuru, Reserva Extrativista Municipal Beija-Flor Brilho de Fogo e um trecho da Floresta Estadual de Produção) e de terras indígenas (Waiãpi), identificadas como zonas-tampãa ${ }^{6}$ (BRASIL, 2005), com reflexos e impactos para e na configuração da política territorial amapaense e dos municípios envolvidos, bem como no processo de concentração urbana amapaense e no entorno dessas áreas.

ii) a configuração de espaços de restrição no lado oeste do estado do Amapá, sem considerar a escala municipal para o planejamento e gestão de seus territórios. $\mathrm{O}$ Parque Nacional Montanhas do Tumucumaque, por exemplo, ocupa áreas de cinco municípios integrantes da faixa de fronteira.

iii) o não envolvimento da escala municipal para e na configuração da sua política territorial, de sua gestão territorial.

iv) a elaboração de propostas capazes de estimular dinâmicas socioeconômicas fronteiriças;

v) a criação e construção de ajustes espaciais de espaços fronteiriços, desarticulados com a linha de fronteira, mas inseridos na Faixa de Fronteira brasileira, com baixa densidade demográfica, com ocorrência de zonas-tampão em grande escala e detentor de uma biodiversidade e de matérias-primas de interesse internacional.

Com a construção da ponte sobre o rio Oiapoque, a construção e pavimentação da rodovia entre Saint-George e Caiena, a pavimentação da rodovia entre Macapá e Oiapoque, e a retomada da mineração nos municípios de Serra do Navio e de Pedra Branca do Amapari tem-se a expectativa de que novos ajustes espaciais sejam necessários para rever como novas dinâmicas espaciais serão construídas sobre as novas políticas territoriais, as novas relações econômicas e sociais, os novos usos desta fronteira e, também, como as novas condições fronteiriças internas e as novas sub-regionalizações são elaboradas do espaço amapaense, a exemplo da proposta indicada por Porto (2014) ao analisar a faixa de fronteira na escala amapaense: a setentrional, a ocidental, a central e a meridional.

A faixa de fronteira setentrional abrange os municípios de Oiapoque e Calçoene e apresenta uma interação espacial com a fronteira Brasil-Guiana Francesa em um processo recente de transfronteirização; há, ali, a ocorrência de áreas protegidas de

\footnotetext{
${ }^{6}$ Segundo o Grupo Retis, o termo pode ser aplicado às zonas estratégicas onde o Estado central restringe ou interdita o acesso à faixa e à zona de fronteira, criando parques naturais nacionais, áreas protegidas ou áreas de reserva, como é o caso das terras indígenas. Mesmo que em certos locais exista uma relação de tipo cultural ou de ordem comercial ou uma combinação deles para justificar sua criação, a situação de bloqueio espaço-institucional 'pelo alto', ou seja, pelo governo central, pode criar uma dicotomia espacial com potencial de conflito entre o institucional e os nexos de passagem e expansão espontânea do povoamento no nível local. (http//igeo-server.igeo.ufrj.br/fronteiras/programafronteira/tiki-index.php?page=Zonastampão).
} 
grande extensão influenciando no uso de seu território; área que possui dupla característica de seus municípios quanto à sua localização na Faixa de Fronteira: a) a faixa possui contato direto com a linha de fronteira Brasil-Guiana Francesa pelo Oiapoque; b) e Calçoene se encontra dentro da faixa de fronteira brasileira, sendo que conecta a linha de fronteira e a acessa por via rodoviária, e sua sede municipal localiza-se fora da faixa.

A faixa de fronteira ocidental envolve os municípios de Serra do Navio e Pedra Branca do Amapari; encontra-se dentro da faixa de fronteira brasileira, mas não conecta a linha de fronteira e nem a acessa; as suas sedes municipais localizam-se fora da faixa; possui na atividade da extração mineral pelo capital internacional a principal atividade e a ocorrência de áreas protegidas de grande extensão, influenciando no uso de seu território.

A faixa central se encontra dentro da faixa de fronteira brasileira; conecta a linha de fronteira e a acessa por via rodoviária; há ocorrência de áreas protegidas, influenciando no uso de seu território, com destaque à Flota e à Reserva Biológica do Lago Piratuba; as suas sedes municipais localizam-se fora da faixa; integram esta subárea os municípios do Amapá, Pracuúba e Ferreira Gomes.

A faixa de fronteira meridional se encontra dentro da faixa de fronteira brasileira; conecta a linha de fronteira, mas não a acessa; sua sede municipal localiza-se fora da faixa; possui forte influência do Complexo Industrial do Jari e a ocorrência de áreas protegidas de grande extensão, influenciando no uso de seu território; integra esta subárea o município de Laranjal do Jari.

Enquanto a primeira é a única que atua em interações transfronteiriças, as demais faixas se manifestam com relações fronteiriças.

Considerando que os municípios de Oiapoque, Serra do Navio e Pedra Branca do Amapari possuem integração ampla com a comunidade indígena e possuem TI demarcadas em seus territórios, a reinvenção do uso destes espaços possivelmente implicará em conflitos de invasão de terras e no aumento da prostituição, o que já é perceptível principalmente com a recuperação da economia mineira. Assim, políticas públicas são requeridas e teriam que já estar operando de forma preventiva.

\section{O oeste amapaense: uma fronteira desconectada com a linde e inteirada com o mundo}

As riquezas minerais encontradas e exploradas nos atuais municípios de Serra do Navio e Pedra Branca do Amapari contribuíram para: a gênese da organização territorial e econômica amapaense; o estímulo para a construção de sistemas de engenharia, a fim de se criarem condições necessárias para a reprodução do capital 
a partir da economia mineira; a criação de ajustes espaciais no espaço amapaense para a criação de adaptações à nova dinâmica e uso do território; e a configuração das redes econômicas do estado do Amapá, ampliando a sua inserção no cenário internacional ${ }^{7}$. Com isso, o Amapá é inserido, é inteirado, é articulado, é conectado e acionado para garantir e acompanhar as mudanças técnicas e tecnológicas elaboradas e implementadas; desconstruir e superar as barreiras espaciais; e redesenhar suas relações espaciais.

Sobre o primeiro aspecto, a dinâmica espacial geoeconômica amapaense tem se assentado sobre as atividades minerais como base para a balança comercial, cuja produção é oriunda desses municípios. Sobre o segundo, foram construídas vias de fluidez (BR-210; Perimetral Norte; Ferrovia Serra do Navio-Santana; Usina Hidrelétrica de Coaracy Nunes, Company Town de Serra do Navio), que permitiram a conexão e o acionamento do oeste amapaense na economia-mundo. No terceiro, criaram-se condições para que o capital se manifestasse e ganhasse movimento, seja na implantação de sistemas de engenharia, na criação de sistema de normas destinadas à fronteira, seja na criação de novos municípios. O último consolida a inserção, a interação e a articulação do Amapá na economia-mundo.

Embora os municípios de Serra do Navio e Pedra Branca do Amapari não estejam conectados à linha de fronteira brasileira, estão situados dentro da faixa fronteiriça do território nacional. Para que suas articulações econômicas sejam efetivadas, devem sair da faixa em direção ao porto de Santana (AP), por onde exportam seus produtos de mineração. Ou seja, as relações e interações espaciais fronteiriças são predominantes nas ações para o uso do território lindeiro, onde se identificam ações atuantes em apenas um lado da fronteira, com forte atuação de efeitos-barreira em sua dinâmica sócio-espacial.

Segundo o Plano de Desenvolvimento da Faixa de Fronteira - PDFF (BRASIL, 2010, p. 17), há dois grupos de municípios e suas relações com a fronteira localizadas na faixa de fronteira brasileira: os lindeiros e os não lindeiros. Para atender aos objetivos deste projeto, adotar-se-ão os municípios encontrados no primeiro caso, que se subdividem em: 1) aqueles em que o território do município faz limite com o país vizinho e sua sede se localiza no limite internacional, podendo ou não apresentar uma conurbação ou semiconurbação com uma localidade do país vizinho (cidades-gêmeas); 2) aqueles cujo território faz divisa com o país vizinho, mas cuja sede não se situa no limite internacional; e 3) aqueles

\footnotetext{
${ }^{7}$ Até a década de 1990, as minas exploradas localizavam-se no território do município de Macapá. A partir daquela década, com a criação dos Municipios de Serra do Navio e de Pedra Branca do Amapari, novas dinâmicas de gestão políticas-administrativas foram inseridas. Com a criação do Parque Nacional Montanhas do Tumucumaque (2002), ampliou-se o espaço de restrição do território amapaense (PORTO, 2005; 2010a), sendo que mais de 70\% do território dos municípios de Serra do Navio e Pedra Branca do Amapari em sua porção ocidental foram afetados (ARAÚJO, 2010).
} 
cujo território faz divisa com o país vizinho, mas sua sede está fora da faixa de fronteira.

Para o caso da fronteira setentrional da Amazônia brasileira, em especial para o caso amapaense, a busca de alternativas econômicas para seu sustento inicialmente com a exploração mineral, posteriormente se preocupando com a proteção de seu patrimônio natural e mais recentemente construindo a sua interação com o Platô das Guianas, a partir da Guiana Francesa - passou a apresentar novas características e novos usos do território, como estratégico recomposto e tardio (PORTO, 2014).

Para o caso amapaense, oito municípios integram a faixa: Oiapoque, Laranjal do Jari, Amapá, Serra do Navio, Pedra Branca do Amapari, Calçoene, Pracuúba e Ferreira Gomes. O conjunto desses municípios envolvidos na faixa de fronteira amapaense ocupa 73\% do espaço do estado do Amapá; detém 14\% da população estadual; e uma densidade demográfica de 66 hab. $/ \mathrm{km}^{2}$. Nesta faixa encontram-se as principais e maiores áreas protegidas instaladas, afetando, sobremaneira, a área de cada município no contexto estadual, principalmente os de Laranjal do Jari e Oiapoque.

Com a estadualização, as expectativas criadas pelas novas relações deste novo estado com o federalismo brasileiro estimularam reflexões que buscam alternativas econômicas para seu sustento, preocupando-se com a proteção ao seu patrimônio natural e com sua comunidade autóctone. Neste sentido, vários temas podem ser trabalhados, tais como: o processo de urbanização da faixa de fronteira; as interações espaciais fronteiriças e transfronteiriças; a fluidez do capital em processos legais e ilegais que subestimam os dados oficiais voltados para o planejamento; as novas reflexões sobre a defesa territorial desta faixa; os novos usos do território na linde amazônica; e a construção da condição fronteiriça amapaense.

\section{A condição estratégico-periférica da fronteira oeste amapaense}

Para se refletir sobre a condição fronteiriça do oeste amapaense e sua construção a partir da análise do uso de seu território, indica-se o processo de exploração do mineral, inicialmente com a garimpagem aurífera pelos samaracás na década de 1930, que vieram da Guiana Francesa e subiram o rio Amapari em busca de ouro; posteriormente, após a segunda metade da década de 1940, quando a empresa Indústria e Comércio de Minérios (ICOMI) venceu a licitação internacional para a exploração do manganês.

Segundo Pinheiro da Silva (2013), quatro períodos são identificados no processo de formação histórica do município de Pedra Branca do Amapari: o início da década de 1950, com a vinda das primeiras famílias de agricultores para a região; a 
década de 1970, com dupla manifestação territorial, devido a instalação e a saída da empreiteira Mendes Júnior, atraindo trabalhadores para a construção civil da rodovia BR-210; a década de 1980, quando há a retomada da garimpagem, ainda que, após 1989, tenha havido o declínio do garimpo na região e o retorno de muitas famílias as atividades agrícolas; por último, a fase pós-1992, quando ocorreu a sua emancipação.

Barbosa (2011), por sua vez, apresenta uma periodização assim identificada: na década de 1930 há a presença de crioulos (samaracás) vindos da Guiana Francesa buscando ouro; na década de 1950, a chegada de trabalhadores para a instalação da ICOMI; na década de 1970, o vilarejo é acessado pela Rodovia BR-210 (conhecida como Perimetral Norte), integrando o Programa de Integração Nacional (PIN); e após 1992, com a emancipação de Pedra Branca do Amapari como município, com dois subperíodos: a) 1992-2004, com atividades garimpeiras e exploração madeireira para a manutenção da Estrada de Ferro do Amapá; b) 2005-2010, após a instalação de investimentos empresariais internacionais para a exploração aurífera.

A partir das obras citadas e de Porto (2003), adequando-se às reflexões aqui tecidas, quatro períodos podem ser identificados para a historicidade da condição fronteiriça do oeste amapaense, tendo por base para essa periodização os fenômenos geoeconômicos institucionalizados de gestão e uso do território. A identidade histórico-temporal está assim indicada:

\section{a) 1946-1957: gênese, estruturação produtiva e construção infraestrutural}

Porto (2003, p. 112-127), ao indicar a primeira periodização econômica para o estado do Amapá (1943-1974), analisa uma série de ações e atividades que afetaram o uso do território amapaense. Indica a criação do Território Federal do Amapá (1943) como marco institucional para novos usos da fronteira, sob a justificativa da defesa nacional, e o comportamento dos setores econômicos, com destaque à exploração manganesífera ${ }^{8}$.

\footnotetext{
8 Vários autores analisaram a atuação da principal atividade econômica, a exploração manganesífera e seus impactos no uso do território amapaense, dentre os quais se destacam: Porto (2013), por exemplo, expõe as principais ações do capital internacional no espaço amapaense; Drummond e Pereira (2007) focalizam particularmente a mina de manganês de Serra do Navio, primeiro empreendimento mineral moderno e de grande porte realizado na Amazônia brasileira e que polarizou a modesta economia do Amapá de 1953 a 1997; Chagas (2013) analisa a atividade mineradora no Amapá, e no Brasil; os conflitos socioambientais; uma sugestão de resolução dos conflitos; e a constatação do autor sobre a falta de base de formulação teórica aplicada à sustentabilidade da mineração.
} 
Após a verificação da potencialidade nas reservas de manganês, o Governo brasileiro sancionou o Decreto-Lei $n^{\circ}$ 9.858, de 13/9/1946, que qualificava a jazida como reserva nacional, identificando, com isso, a primeira referência oficial e institucionalizada de uma condição estratégica para o país e de interesse do capital internacional (doze dias após a publicação daquele diploma legal, um edital do Governo convocava os interessados a licitação de exploração desta jazida, concorrendo as empresas: Companhia Meridional de Mineração (subsidiária da U.S. Steel), Hanna Exploration Company, de Pittsburgh (EUA) e a Sociedade Indústria e Comércio de Minérios Ltda - ICOMl (Brasil). A vencedora foi a Icomi ${ }^{9}$, sendo assinado o contrato com o Governo do então Território Federal do Amapá em 1947, materializando, com isso, a condição estratégica dessa fronteira ${ }^{10}$.

Com isso, havia necessidade de ajustes espaciais em infraestrutura para maior interação e acionamento desse espaço no cenário global. A partir da década de 1950, com a vinda das primeiras famílias de agricultores para a região na década de 1950 (PINHEIRO DA SILVA, 2013), fornecendo alimentos para o canteiro de obras, há também a chegada de trabalhadores para atuarem na construção de todo sistema de engenharia do empreendimento (ferrovia, rodovia, porto, duas usinas termoelétricas, usina hidrelétrica, duas company towns - Serra do Navio e Vila Amazonas), articulando o oeste amapaense com o litoral na exportação de minérios. Assim, com a exploração e exportação do manganês, em meados da década de 1950, a participação dos valores de produção mostraram radical transformação na economia amapaense (PORTO, 2003).

Enquanto período de construção do empreendimento da Icomi, com diversificação de investimentos no espaço amapaense, a instalação de sistemas de engenharia, originando o Grupo CAEMI (Companhia Auxiliadora de Empresa de Mineração) ${ }^{11}$, criaram-se condições para a emancipação de espaços distritais, como ocorreu com Santana (onde se encontra a Vila Amazonas) e Serra do Navio.

\footnotetext{
${ }^{9}$ Dois contratos foram assinados para a exploração do manganês pela Icomi. No primeiro, institucionalizado pelo Decreto $N^{\circ} 24.156$ de 04/12/1947, a empresa apresentava-se como Sociedade Limitada. Posteriormente, esse diploma legal foi revisto pelo Decreto $n^{\circ} 28.192$ de 21/05/1950, alterando sua condição para Sociedade Anônima. Isto sugere a participação acionária da Bethlehem Steel na Icomi (SILVA, 1988).

${ }^{10}$ Segundo Porto (2003, p. 118), “a instalação da Icomi marcou o início da produção industrial e extrativa mineral na Amazônia, com a venda do minério voltado ao mercado norte-americano, com apoio financeiro da rede bancária e creditícia regional e empréstimos internacionais. Essa atividade foi a primeira executada na Amazônia no pós-guerra, por mineradoras estrangeiras e em ritmo industrial".

${ }^{11}$ Segundo Porto (2003) uma consequência do contrato para a exploração do manganês, diz respeito à previsão da criação de associações com empresas de origem estrangeira: a Icomi uniu-se com a norte-americana Bethlehem Steel Company, que desde 1949 vinha dando apoio financeiro aos trabalhos de prospecções realizados em Serra do Navio. Em decorrência disso, surgiu a Caemi em 1950, cujo acionista majoritário era o próprio dono da empresa mineradora de manganês no Amapá.
} 
b) 1957-1997: a consolidação, reestruturação e institucionalização espacial

Passado o período de criação de condições para outros usos do território do oeste do Amapá, inicia-se o período de consolidação dos investimentos efetivados ${ }^{12}$ e a reestruturação das atividades, culminando com a saída do Grupo Caemi do espaço amapaense, capitaneado pela empresa Icomi.

O fluxo e a fluidez da exportação mineral tomam ritmo. Em 1956, o Amapá era responsável por somente $0,04 \%$ da exportação da região Norte. No ano seguinte, passou para 60,4\%, quando ocorreu a primeira exportação do manganês pelo Porto de Santana (AP), de 668.276 toneladas, o que correspondeu a 83,7\% da exportação nacional deste minério. Assim, com a infraestrutura montada, créditos bancários efetivados e estímulos de políticas públicas estabelecidos, a exportação atingiu seu auge na década de 1980.

$\mathrm{Na}$ década de 1970, destacam-se as atividades e investimentos da empreiteira Mendes Júnior na construção da rodovia BR-210, integrando o Programa de Integração Nacional (PIN). Na década de 1980 há a retomada da garimpagem, porém, com seu declínio no final desta década, há o retorno para atividades agrícolas.

Na década de 1990, há uma série de ações institucionais que afetam diretamente a organização do espaço envolvendo Serra do Navio $^{13}$ e Pedra Banca do Amapari ${ }^{14}$. Dentre as quais se destacam:

i) a promulgação da Constituição Estadual amapaense (1991) que, em seu art. $4^{\circ}$ das Disposições Transitórias, estabelece a consulta plebiscitária para emancipação política de 22 novos municípios, sendo que Serra do Navio e Pedra Branca do Amapari estão inseridos neste rol, cujas emancipações foram efetivadas em 1992.

\footnotetext{
${ }^{12}$ Segundo Porto (2003, p. 6), "a partir da década de 1960, este grupo diversifica suas atividades no Amapá, com as seguintes instituições e empresas: Instituto Regional de Desenvolvimento do Amapá, Companhia Progresso do Amapá, as empresas Bruynzeel de Madeira S.A., Companhia Dendê do Amapá S.A., Amapá Florestal Celulose S.A., a aquisição da maioria das ações do Complexo Industrial do Jan (Jari Celulose S.A, Caulim da Amazônia e a Mineração Santa Lucrécia) e a implantação da Companhia de Ferro-Liga do Amapá (CFA)".

${ }^{13}$ O Município de Serra do Navio foi criado em 1992. A cidade foi criada inicialmente para abrigar os funcionários da Icomi, como uma company town. Em seu território foi encontrada uma jazida de manganês que foi explorada por 40 anos (1957-1997), sendo instalado todo maquinário pesado de extração mineral; foi instalada uma estação ferroviária para o embarque de minério de manganês, com destino ao Porto de Santana, visando a exportação para os EUA. Para maiores reflexões sobre este município, vide Ribeiro (1992), Brito (1994), Tostes (2008); Sacramento da Silva (2009).

${ }^{14}$ O Município de Pedra Branca do Amapari foi criado em 1992, no entorno dos investimentos da Icomi e da company town Serra do Navio. Sobre este município, vide Pinheiro da Silva (2013), Tostes (2008); Simões (2008); Gemaque (2010) e; Barbosa (2011).
} 
Com isso o Estado assume as responsabilidades de políticas públicas, se faz presente através dos órgãos públicos e financia sua sobrevivência com os Fundos de Participação dos Municípios (FPM).

ii) A criação e instalação de unidades de conservação e terras indígenas em território de Pedra Branca do Amapari (Terra Indígena Waiãpi, 1996; e a Reserva de Desenvolvimento Sustentável do Rio Iratapuru, 1997), ocupando 36,55\% de suas terras, unidades e TIs que afetam diretamente a sua configuração e política territoriais, criando uma situação complexa para a gestão pública municipal. Acrescente-se, também, que o município não possui um plano diretor urbano.

\section{c) 1997-2004: o desacionamento da fronteira conectada}

Este período é caracterizado pelo desacionamento econômico da fronteira conectada pelo capital internacional, representado pela saída de Icomi e de seus investimentos, o que obrigou o poder público ampliar suas ações de manutenção do território, baseando-se em ações de políticas públicas e no FPM. Dois fatores afetaram diretamente a organização espacial e econômica dos municípios de Serra do Navio e Pedra Banca do Amapari:

a) a saída dos investimentos da Icomi (1997) por dois motivos: o esgotamento de acesso ao mineral pela tecnologia usada; a proximidade do término contratual de exploração (2003), não estimulando novos investimentos pela empresa.

b) a ampliação de espaços de restrições com a criação do Parque Nacional Montanhas do Tumucumaque (2002), chegando este a afetar 34\% do território de Pedra Branca do Amapari (somando aos espaços da Terra Indígena Waiãpi e da Reserva de Desenvolvimento Sustentável do Rio Iratapuru, $71 \%$ do seu território municipal possuem restrições de uso); quanto à Serra do Navio, somente este Parque Nacional representa $72 \%$ do território do município. Essa configuração territorial torna mais complexa tanto a sua organização quanto as políticas territoriais para a gestão pública municipal.

\section{d) 2004-2013: A recuperação e o reuso de um espaço construído}

Esse período é caracterizado pela recuperação econômica por meio da atividade mineral, sendo agora pelo ouro e ferro e pelo retorno do capital internacional do setor (MMX, Anglo Ferrous e a Zanin Ferrous) em 2004. Em 2013, houve o desabamento da estrutura portuária responsável pela exportação mineral do Amapá. Com isso, toda a produção ficou paralisada, enquanto o porto não era reconstruído. 
Sobre este período, o reuso do território apresentou os seguintes comportamentos:

i) a recuperação da economia mineira foi assentada em uma estrutura já estabelecida pela Icomi, ou seja, não houve investimentos de construção, mas de manutenção da infraestrutura ferroviária. Segundo Simões (2008), essa atividade inseriu três municípios do estado do Amapá como maiores recebedores da Compensação Financeira pela Exploração dos Recursos Minerais (CFEM) do país ${ }^{15}$, e o segundo da região Norte, contudo, tais municípios não possuem planos específicos para aplicação no meio ambiente ou numa alternativa econômica futura para a diversificação produtiva ou para o desenvolvimento local.

ii) Não houve planejamento que afetasse a dinâmica de expansão urbana de Pedra Branca do Amapari e de Serra do Navio, como também seus planos diretores;

iii) Não houve a instalação de company towns semelhante a Serra do Navio;

iv) Quanto à criação de novos espaços de restrição que afetam diretamente a organização, a configuração e as políticas territoriais municipais no período, há três destaques: a) em 2006 foi criada a Floresta Estadual de Produção (Flota), envolvendo dez municípios amapaenses, dentre eles Serra do Navio (ocupando 24\% de seu território) e Pedra Branca do Amapari (ocupando 16\%); b) em 2007 foram criadas a Reserva Extrativista Municipal Beija-Flor (Brilho-de-Fogo) em Pedra Branca do Amapari, ocupando 7\% de seu território, sendo completamente sobreposta ao módulo I da Flota; e o Parque Municipal Natural do Canção, em Serra do Navio, ocupando 0,05\% de seu território; c) o núcleo urbano de Serra do Navio foi tombado como patrimônio cultural do Brasil pelo Instituto do Patrimônio Histórico e Artístico Nacional (IPHAN) em 2010.

Com isso, esses dois municípios passaram a apresentar a seguinte configuração territorial:

a) Serra do Navio, com 96\% com restrição de uso do território (Figura 4), cujo núcleo urbano é tombado pelo IPHAN como Patrimônio Cultural do Brasil;

b) Pedra Branca do Amapari (Figura 5), que apresenta 93\% de restrição de uso do território.

\footnotetext{
${ }^{15}$ Segundo Simões (2008), entre os maiores arrecadadores no Amapá estão: Vitória do Jarí, com extração de caulim; Pedra Branca do Amapari, com extração de ouro e ferro; e Mazagão, com extração de cromo. A autora identificou que em Vitória do Jari a arrecadação chega a superar a principal transferência da União àqueles entes federativos: o Fundo de Participação dos Municípios - FPM.
} 
Figura 4 - Participação das áreas protegidas no Município de Serra Navio

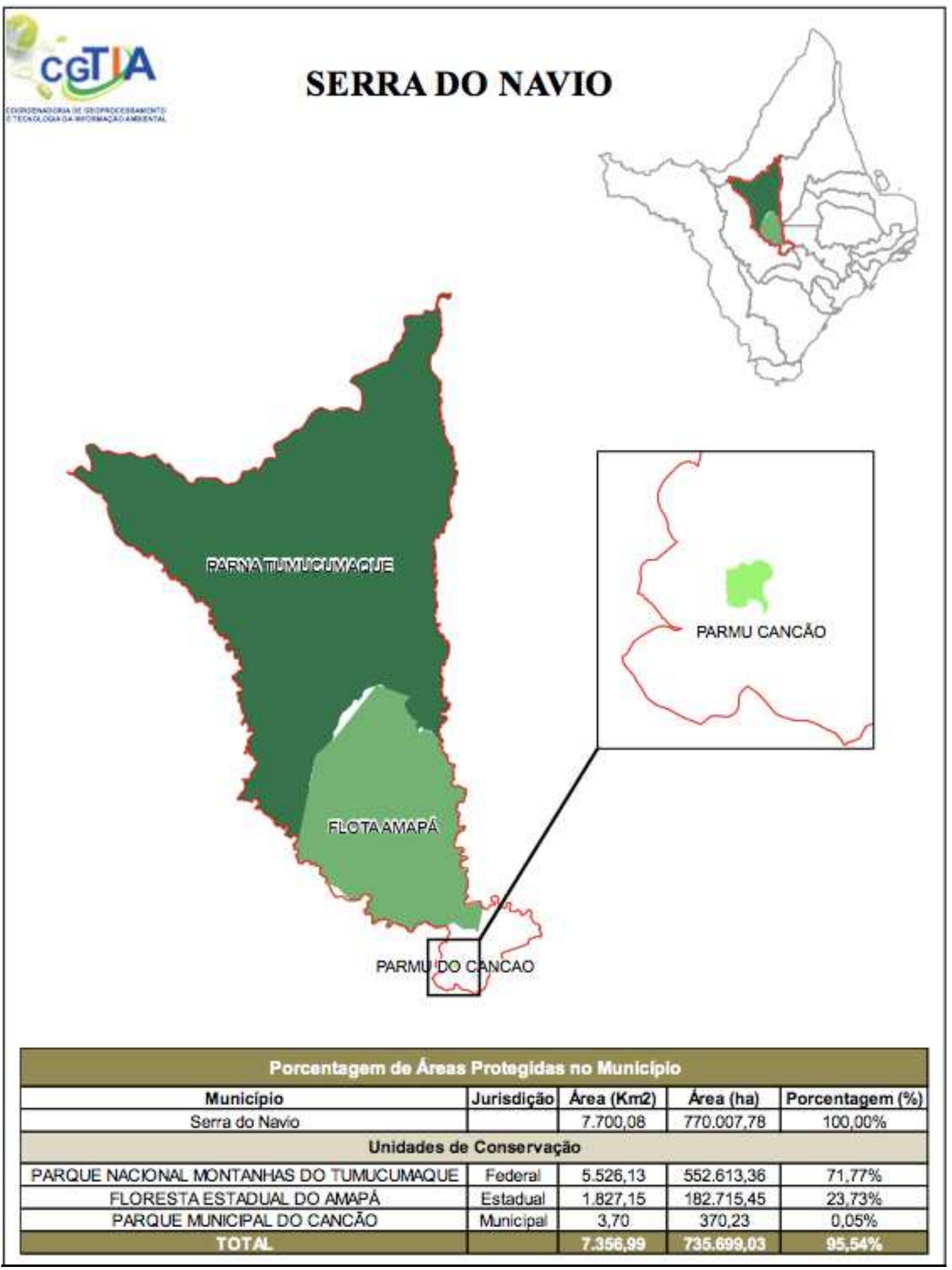

Fonte: SEMA, IEPA. 
Figura 5 - Participação das áreas protegidas no Município de Pedra Branca do Amapari

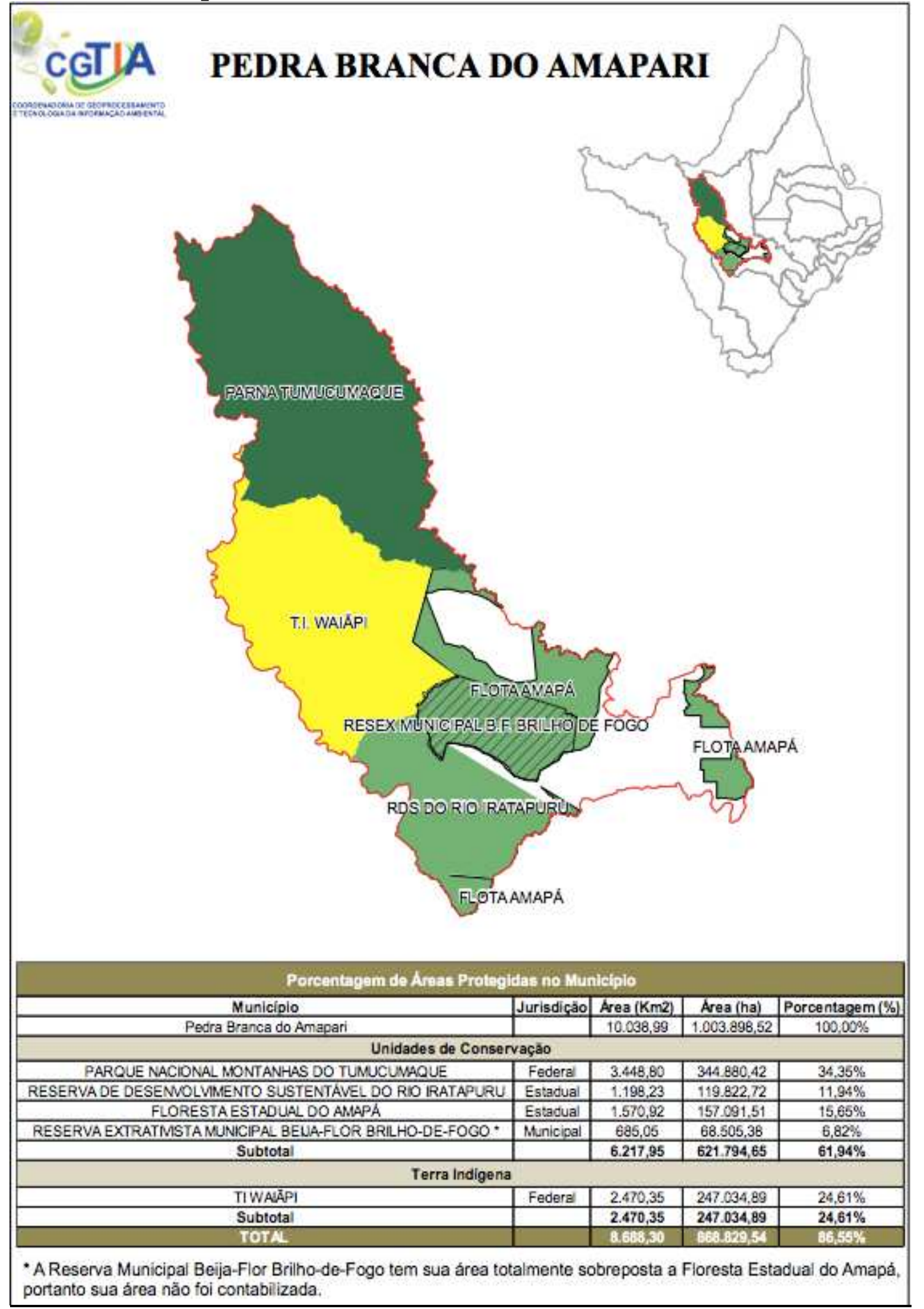

Fonte: SEMA, IEPA. 


\section{Conclusão}

A construção do uso da fronteira ocidental amapaense foi amplamente executada por investimentos públicos e privados que permitiram o seu acionamento e a sua articulação espacial em uma rede internacional do setor mineral. Embora sua interação espacial apresente características precárias de mobilidade (rodovias não pavimentadas, ferrovia e porto superusados), a região é detentora de uma condição fronteiriça estratégico-periférica institucionalizada, em que o "estratégico" se explica pela atração de investimentos internacionais; o "periférico", pela condição de abandono, pelos discursos políticos e pelo elevado grau de dependência dos municípios aos recursos do Estado; e o "institucionalizado" é representado pela grande influência de instituições públicas na gestão territorial dos municípios envolvidos.

Para melhor entender o processo dessa construção, identificam-se quatro períodos para explicar a materialização e a configuração temporal da condição fronteiriça do oeste amapaense, considerando o uso de seu território e o desenvolvimento geográfico desigual: a) 1946-1957: gênese, estruturação produtiva e construção infraestrutural; b) 1957-1997: a consolidação, reestruturação e a institucionalização espacial; c) 1997-2004: o desacionamento da fronteira conectada; d) 2004-2013: a recuperação e o reuso de um espaço construído.

O primeiro período insere a sub-região no contexto do então Território Federal do Amapá, como parte integrante da estratégia de desenvolvimento deste ente federativo a partir dos investimentos e da exploração do setor mineral, criando e construindo ajustes espaciais em infraestrutura para maior interação e acionamento deste espaço no cenário global.

O segundo período indica a fase da consolidação dos investimentos efetivados, a reestruturação das atividades estabelecidas, atraindo trabalhadores para o setor agrícola e mineral, a fim de atender as expectativas da atividade mineira empresarial, culminando com a saída do Grupo Caemi do espaço amapaense, capitaneado pela empresa Icomi. No contexto institucional, as ações se direcionaram para a regulamentação político-administrativa de seu funcionamento, seja para seguir uma demanda constitucional do estado do Amapá, seja para definir espaços políticos de atuação através da criação de novos municípios; e para definir políticas territoriais com a instalação de espaços de restrição sem a preocupação do envolvimento dos municípios na criação, construção e instalação desses espaços.

O terceiro período é caracterizado pelo desacionamento econômico da fronteira conectada pelo capital internacional, representado pela saída de Icomi e de seus investimentos, obrigando ao poder público ampliar suas ações de manutenção do território, baseando-se em políticas públicas e no FPM. Dois fatores afetaram diretamente a organização espacial e econômica: a saída dos investimentos da 
Icomi (1997); e com a ampliação de espaços de restrições tornam-se mais complexas para a gestão pública municipal a sua organização e as suas políticas territoriais.

O quarto período é caracterizado pela recuperação econômica pela atividade mineral. Contudo, com o desabamento da estrutura portuária responsável pela exportação mineral do Amapá, em 2013, toda a produção ficou paralisada enquanto o porto não era reconstruído. Neste período, embora a fronteira apresentasse uma recuperação econômica, os municípios nela envolvidos não apresentaram um avanço e nem planos específicos para aplicação no meio ambiente ou numa alternativa econômica futura, com diversificação produtiva ou com desenvolvimento local; não apresentou planejamentos territoriais que afetassem a dinâmica de expansão urbana dos municípios envolvidos, pelo contrário, acrescentaram-se novos espaços de restrição de outras instâncias (estaduais e federais), que afetam diretamente a organização, a configuração e as políticas territoriais municipais.

Neste sentido, a fronteira ocidental amapaense teve um período de protoconstrução territorial (1946-1957), simplesmente por integrar um ente federativo recém-criado e pela gênese de um investimento externo de exploração mineral. Ela teve dois períodos (1957-1997 e 2004-2013) de ampla inserção, interação/articulação e acionamento pelo capital internacional para desconstruir e superar as barreiras espaciais, considerando o seu acesso. Porém, aí se criaram espaços de restrição quanto à gestão do território, com ajustes espaciais e redesenho de suas relações espaciais. Por fim, teve um período (1997-2004) de hibernação para a fluidez e reprodução do capital e a retomada de políticas públicas para a reconstrução da condição fronteiriça amapaense.

\section{Referências}

ARAÚJO, M. W. R. Configuração do espaço amapaense: um mosaico de territorialidades, 2010. Dissertação (Mestrado em Desenvolvimento Regional) Mestrado em Desenvolvimento Regional, Universidade Federal do Amapá, Macapá, 2010.

BARBOSA, R. G. Os efeitos da mineração na arrecadação e no processo de urbanização do Município de Pedra Branca do Amaparí, 2011. Dissertação (Mestrado em Direito Ambiental e Políticas Públicas) - Mestrado em Direito Ambiental e Políticas Públicas, Universidade Federal do Amapá, Macapá, 2011.

BRASIL. Ministério da Integração. Proposta de reestruturação do Programa de Desenvolvimento da Faixa de Fronteira: bases de uma política integrada de desenvolvimento regional para a faixa de fronteira. Ministério da Integração Nacional, Secretaria de Programas Regionais - Brasília, 2005. 
Ministério da Integração. Bases para uma proposta de desenvolvimento e integração da Faixa de Fronteira. Grupo de Trabalho Interfederativo de Integração Fronteiriça. Ministério da Integração Nacional, Secretaria de Programas Regionais, Brasília, 2010.

BRITO, D. C. Extração mineral na Amazônia: a experiência da exploração de manganês da Serra do Navio no Amapá. Belém, 1994. 120 f. Dissertação (Mestrado em Planejamento do Desenvolvimento) - Mestrado em Planejamento do Desenvolvimento, Universidade Federal do Pará, Belém, 1994.

CARVALHO, D. F. O ciclo da economia brasileira e a Amazônia na dinâmica regional centro-periferia. Paper do NAEA, n. 120, mai., 1999.

CHAGAS. M. A. Amapá: A mineração e o discurso da sustentabilidade - de Augusto Antunes a Eike Batista. Rio de Janeiro: Garamond, 2013.

CHELALA, C. A magnitude do Estado na socioeconomia amapaense, 2008. Dissertação (Mestrado em Desenvolvimento Regional) - Mestrado em Desenvolvimento Regional, Universidade Federal do Amapá, Macapá, 2008.

DORFMAN, A. A condição fronteiriça diante da securitização das fronteiras do Brasil. In: NASCIMENTO, D. M.; PORTO, J. L. R. Fronteiras em perspectiva comparada e temas de defesa da Amazônia. Belém: NAEA/UFPA, 2013.

DRUMMOND, J. A.; PEREIRA, M. A. P. O Amapá nos tempos do manganês: um estudo sobre o desenvolvimento de um estado amazônico (19432000). Rio de Janeiro: Garamond, 2007.

FOUCHER, M. Obsessão por fronteiras. São Paulo: Radical Livros, 2009.

GEMAQUE, I. S. F. C. Territorialidade, agricultura e mineração (Pedra Branca do Amapari-Amapá), 2010. Tese (Doutorado em Desenvolvimento Sustentável) - Programa de Pós-Graduação em Desenvolvimento Sustentável do Trópico Úmido, Universidade Federal do Pará, 2010.

GRIMSON, A. Los processos de fronteirización: flujos, redes e historicidad. In: Frontera territorios $\mathbf{y}$ metáforas. Medelin: Hombre Nuevos Ed./INER/Universidad de Antioquia, 2003.

HARVEY, D. O "novo imperialismo": ajustes espaço-temporais e acumulação por desapossamento. In: Revista Lutas Sociais, v. 13/14, $1^{\circ}$ sem., 2005. Disponível em: http://www.pucsp.br/neils/downloads/v13_14_harvey.pdf. 
Os limites do capital. São Paulo, Boitempo, 2013.

MELLO, J. M. C. O capitalismo tardio: contribuição à revisão crítica da formação e do desenvolvimento da economia brasileira. 10 ed. Campinas: IE/Unicamp, 1998.

PEREIRA, M. F. V. A inserção subordinada do Brasil na divisão internacional do trabalho: consequências territoriais e perspectivas em tempos de globalização. Sociedade Natureza (Online), v. 22, n. 2, Uberlândia, Ago., 2010. Disponível em: http://dx.doi.org/10.1590/S1982-45132010000200009.

PINHEIRO DA SILVA, R. Riscos associados às inundações na área urbana do Município de Pedra Branca do Amapari - Amapá. 2013. Dissertação (Mestrado em Desenvolvimento Regional) - Mestrado em Desenvolvimento Regional, Universidade Federal do Amapá, Macapá, 2013.

PORTO, J. L. R. Amapá: principais transformações econômicas e institucionais 1943 a 2000. Macapá: SETEC, 2003.

Aspectos da ação do estado na fronteira amazônica: a experiência do território Federal/Estado do Amapá. Macapá: Jadson Porto, 2005. (Série Percepções do Amapá, v. 2).

- A condição fronteiriça amapaense: da defesa nacional à integração (inter)nacional. In: NASCIMENTO, D. M. Amazônia e Defesa: dos fortes às novas conflitualidades. Belém (PA): (NAEA/UFPA), 2010a.

- A condição periférico-estratégica da Amazônia Setentrional: a inserção do Amapá no Platô das Guianas. In: PORTO, PORTO, J. L. R.; NASCIMENTO, D. M. Interações fronteiriças no Platô das Guianas: novas construções, novas territorialidades. Rio de Janeiro: Editora Publit, 2010b.

- Reinvenções do uso do território amapaense. In: SIMONIAN, L. T. L. (Org.). Políticas públicas, desenvolvimento, unidades de conservação e outras questões socioambientais no Amapá. Belém: NAEA/UFPA, 2010c, v. 1, pp. 91-113.

Expectativas da fronteira da Amazônia Setentrional: a busca pela interação do Platô das Guianas. In: PORTO, J. L. R; NASCIMENTO, D. N. Dinâmicas periférico-estratégicas da fronteira da Amazônia Setentrional: das políticas públicas e redes institucionais à integração espacial. Rio de Janeiro: Editora Publit, 2013. 
Desenvolvimento geográfico desigual da faixa de fronteira da Amazônia setentrional brasileira: reformas da condição fronteiriça amapaense (1943-2013), 2014. Relatório de estágio de pós-doutoramento, Universidade Regional de Blumenau, Blumenau, 2014.

PORTO, J. L. R; COUTO, M. E. A.; BARROZO, J. M.; SANTOS, M. M.; THALEZ, G. M. Do Território Federal a Estado: condicionantes para a execução de ajustes espaciais no Amapá - Brasil. In: BRASIL, W.; MIRTIL, E.; MACIEL, F. (Org.). 35 anos de colonização da Amazônia: Rondônia. Porto Velho: EDUFRO, 2007. p. 188-198.

PORTO, J. L. R ; SUPERTI, E.; SILVA, G. V.; Novos usos do território amapaense: políticas públicas, desenvolvimento, ajustes espaciais na fronteira da Amazônia Setentrional. Macapá, Datil, 2013.

REIS, A. C. F. Limites e demarcações na Amazônia brasileira. Belém: SECULT, 1993. 2 v. (Série Lendo o Pará; 15).

RIBEIRO, B. A. Vila Serra do Navio: comunidade urbana na selva amazônica: um projeto do arq. Oswaldo Arthur Brake, São Paulo, PINI, 1992.

ROMANI, C. Clevelândia, Oiapoque - Aqui começa o Brasil! Trânsitos e confinamentos na fronteira com a Guiana Francesa (1900 - 1927), 2003. Tese (Doutorado de História) - Programa de Pós-Graduação em História, Universidade Estadual de Campinas, 2003.

SACRAMENTO DA SILVA, L. S. Impactos observados na infraestrutura urbana dos municípios de Serra do Navio e Pedra Branca do Amapari no período de 1999-2008. Macapá: MDR/UNIFAP, 2009. Dissertação (Mestrado em Desenvolvimento Regional).

SANTOS, M. A natureza do espaço: Técnica e tempo. Razão e emoção. São Paulo: Hucitec, 1996.

SILVA, G. V. Usos contemporâneos da fronteira franco-brasileira: entre os ditames globais e a articulação local, 2008. 180 f., il., anexos. Dissertação (Mestrado em Geografia) - Programa de Pós-Graduação em Geografia, Universidade Federal do Rio Grande do Sul, Porto Alegre, 2008. 
SILVA, R. G. A quinta-coluna no setor mineral: o entreguismo dos minérios. Porto Alegre: Tchê, 1988.

SIMÕES, H. C. G. Q. Avaliação da compensação financeira pela exploração dos recursos minerais no Estado do Amapá. Macapá: PPGBIO/UNIFAP, 2008. Dissertação (Mestrado em Direito Ambiental e Políticas Públicas) Programa de Pós-Graduação em Direito Ambiental e Políticas Públicas, Universidade Federal do Amapá, Macapá, 2008.

TOSTES, J. A. Serra do Navio e Pedra Branca do Amapari: entre a esperança e a vulnerabilidade urbana e ambiental. In: Seminário Internacional - Amazônia e Fronteiras do Conhecimento, NAEA/UFPA, 9-11 de dezembro de 2008, Belém (PA). Anais... Disponível em: http://www.ufpa.br/naea/siteNaea35/anais/html/ geraCapa/FINAL/GT6-209-1240-20081124192415.pdf.

Endereço para correspondência:

Jadson Luís Rebelo Porto - jadsonporto@yahoo.com.br

Rod. Juscelino Kubitscheck, Km 1

68900-280 Macapá/AP, Brasil 